International Journal of Social Science And Human Research

ISSN(print): 2644-0679, ISSN(online): 2644-0695

Volume 04 Issue 01 January 2021

DOI: $10.47191 / \mathrm{ijsshr} / \mathrm{v} 4-\mathrm{i} 1-03$

Page No : $18-22$

\title{
Use of Application Variations on Online Teaching in the Covid-19 Pandemic Era
}

\author{
Sitti Patima. $\mathbf{H}^{\mathbf{1}}$, Kemas Imron Rosyadi ${ }^{2}$, Sukarno ${ }^{3}$ \\ ${ }^{1}$ Islamic Education Management Department, Postgraduate, UIN Sulthan Thaha Saifuddin-Jambi \\ ${ }^{2}$ Educational Management Department, Postgraduate, UIN Sulthan Thaha Saifuddin-Jambi \\ ${ }^{3}$ Science Education (Physics) Department, Faculty of Tarbiyah and Teacher Training, UIN Sulthan Thaha Saifuddin-Jambi
}

\begin{abstract}
This study aims to find out the problems and solutions experienced by teachers during the Covid-19 pandemic where teachers have to do online learning. This research is a descriptive study using an online survey method. The data was collected using an online questionnaire to 25 respondents to the teachers of SMAN 2 Tanjung Jabung Timur. It was found that $100 \%$ of the respondents of SMAN 2 Tanjung Jabung Timur had conducted online learning during the Covid-19 pandemic. Based on the research results, it was found that $100 \%$ of the teachers were learning the online model (online). Also, in the implementation of online learning teachers use various applications including WhatsApp Web, Google Classroom, Zoom Meeting and Webinar, Youtube. The main application choice for teachers is WhatsApps, which is $100 \%$ of teachers claiming to be the first choice.
\end{abstract}

KEYWORDS: Variations of online learning applications, Online Learning, Covid-19 Pandemic

\section{INTRODUCTION}

The 2019 Coronavirus disease pandemic (COVID-19) is an ongoing problem in more than 200 countries around the world. According to Siahaan (2020), Indonesia is one of the countries affected by Covid-19 pandemic. Indonesia is severely affected by COVID-19 with a case fatality rate (CFR) of 8.9\% (Setiati \& Azwar, 2020). In early 2020, COVID-19 became a world health problem. This case originated from information from the World Health Organization (WHO) on December 31, 2019, which stated that there was a pneumonia cluster case with unclear etiology in Wuhan City, Hubei Province, China. This case continues to grow until there are reports of deaths and imports outside China (Kemenkes RI, 2020).

The COVID-19 pandemic that is spreading, in the end, carries a very bad risk for the world economy including Indonesia, especially in terms of tourism, trade, and investment (Nasution, et al., 2020). Covid-19 is an infectious disease that has the potential to cause a public health emergency. Therefore, preventive measures against this type of infectious disease must be taken as soon as possible. Indonesia as a rule of law, therefore the prevention of these types of infectious diseases must be stipulated in regulation or regulation. The same thing was expressed by Yunus \& Rezki (2020) that Indonesia has experienced conditions where public concern for Covid-19 is quite large so that a government policy is needed to carry out a lockdown, as an effort to break the chain of spreading the Covid-19 coronavirus.

One of the government policies in the field of education as an effort to prevent COVID-19 is the temporary closure of the learning process in schools as a result of the program so that the stay at home or work from home (WFH) program is implemented as an effort to suppress the expansion of Covid-19 (Darmalaksana, et al. al., 2020), (Dewayani, 2020) and (Tri \& Dengkek, 2020). Regarding this, the Ministry of Education and Culture took a firm stance through several circular letters related to education policies in the emergency period of the spread of Covid-19 (Firman \& Rahayu, 2020).

Implementation of learning must be done online using the internet network. The temporary closure of educational institutions to contain the spread of the Covid-19 pandemic so that it has an impact on the learning process in informal educational institutions. This is also in line with the statement (Windhiyana, 2020) that during COVID-19 the learning model in informal educational institutions was very drastic. All learning activities are carried out online, from elementary school to university level. This situation certainly has an impact on student psychology and reduces the quality of student skills (Syah et al., 2020).

The covid-19 pandemic has brought big changes to the world, including Indonesia. The spread of the coronavirus is the cause of the highest death rate for now (Pane, 2020). Various countries have implemented social distancing which is designed to reduce interactions between people in the wider community, where individuals may be infected but have not been identified so that they 


\section{Use of Application Variations on Online Teaching in the Covid-19 Pandemic Era}

have not been isolated (Darmalaksana et al., 2020). This has a major impact on all sectors of life. This has resulted in the closure of many educational facilities, shopping centers, and so on (Amira et al., 2020).

The policies issued to limit the spread of the coronavirus have an impact on various fields around the world, especially in education (Burhanuddin \& Abdi, 2020). Learning that should be done face-to-face turns into online learning. Online learning, online or distance learning itself aims to meet educational standards by utilizing information technology using computer devices or gadgets that are connected between students and teachers and between students and lecturers so that through the use of these technologies the teaching and learning process can be carried out properly (Anugrah, 2020). An implementation that is not bound by time and without face-to-face is an advantage of online learning that can be used by teachers (Sety et al., 2020).

This highly changing learning system has had a major impact on the world of education. This change in learning is a condition that requires entering information literacy in academic culture (Yahaya \& Abd. Majid, 2011). One of the causes of this major change is that online learning is carried out suddenly, this has a major impact on the readiness of schools, teachers, and students in carrying out inadequate learning. Moreover, the impact of the corona pandemic that hit so that learning did not run optimally because they had to stay at home and apply physical distancing (Ismail \& Zainal Abidin, 2010). By studying at home, the greatest difficulty faced by teachers is when implementing the learning method at home. Therefore, all means must be done so that there is a significant increase even though the learning is done online. The role of parents is needed when this online learning takes place (Warisyah, 2015)

The spread of the coronavirus has resulted in staff and students becoming victims of this virus outbreak. The impact felt by students is negative because they are "forced" to do learning from home. Moreover, many students who are not used to learning online have never even experienced learning online. This becomes an obstacle in the learning process which can reduce student interest in learning (Suryani et al., 2020). Especially with the condition of teachers who do not understand internet technology or the use of various online learning media especially those in the regions. This results in less efficient learning, lack of student concentration, and difficulty for students to understand, ask, and answer questions and discuss the material studied during online learning (Suryani et al., 2020).

Online learning is certainly a new challenge for teachers who make them have to master online learning media to carry out learning activities and are expected to be able to be creative in the learning process so that learning objectives can be maximally achieved (Suryani et al., 2020). When learning activities take place, it is necessary to pay attention to effectiveness, in other words, the level of success achieved. The characteristics of the effectiveness of the learning program are successfully delivering students to achieve predetermined instructional goals, providing attractive learning experiences, involving students actively to support the achievement of instructional goals and having the means that support the teaching and learning process (Sudjana, 2019). The effectiveness of learning is not only seen from student learning outcomes but also must be seen in terms of the learning process. Therefore, the focus of this research is to understand the variation of applications used during the implementation of online learning by teachers, especially for teachers who are in the Muara Sabak Timur area.

\section{METHOD}

This research is a qualitative descriptive study using an online survey method. Primary data collection was carried out by distributing questionnaires online to 25 respondents at SMAN 2 Tanjung Jabung Timur school who were affected by the Covid-19 pandemic. Besides, supporting data is secondary data from documents, articles, or news related to online learning during COVID-19. Respondents are teachers who are more than 25 years old. The gender of the 25 respondents, on average, was $84.4 \%$ female and $15.6 \%$, male. The latest education is that all respondent teachers have an undergraduate education. Respondents in this study were teachers from the regions in the Tanjung Jabung Timur district. The distribution of respondents to teachers of SMAN 2 Tanjung Jabung Timur class X-XII and teachers in the field of study, namely English, PAI, and 4 respondents did not mention the class they were teaching. There are $88 \%$ of teachers from class X to class XII and $12 \%$ of teachers in the field of study. The principal urged to carry out online learning, $100 \%$ or as many as 25 teachers doing online learning. The data was obtained by filling in the questions that were distributed to all respondents in the form of a Google Form. Furthermore, the collected data were analyzed for description.

\section{RESULT AND DISCUSS}

The learning media used by teachers at SMAN 2 Tanjung Jabung Timur are said to be WhatsApps (WA), Google Classroom, Google Drive, Youtube, WA group. As many as $81 \%$ of teachers at SMAN2 Tanjung Jabung Timur answered with several underlying reasons for doing online learning. The first reason was answered by 20 respondents that due to the COVID-19 pandemic season, teachers needed to do online learning to break the chain of the spread of the outbreak. Besides, so that during the pandemic students continue to learn, the most efficient learning to reduce crowds and virus transmission is learning by following recommendations from the government, namely learning online models.

The second reason was responded to by 20 teachers by answering more on the responsibilities, obligations, and duties of a teacher to do learning even though it was online. Teachers have an obligation to carry out learning for whatever reasons. The online 


\section{Use of Application Variations on Online Teaching in the Covid-19 Pandemic Era}

model used by the teacher is to use WhatsApps (WA), Google Classroom, Google Drive, Youtube, WA group, and some even have face-to-face meetings with the Zoom Meeting application twice a week.

The online learning model which is the first choice used at SMAN 2 Tanjung Jabung Timur, namely as many as 100\% of the teachers use the WA facility or often known as WhatsApps, where the teacher creates a WhatsApp group so that all students can be involved in the group. Tasks are given via WhatsApps. Even if students still don't understand, the teacher will also add by sending videos or doing WhatsApps Video Calls with students. Even collecting assignments makes it easier for students via WhatsApps messages. Assignments can also be sent via WhatsApps and usually, students take photos of the assignments and send them to the teacher. Even the tutorial videos made by the teacher are also uploaded via WhatsApps. Furthermore, students download the material and study the material from the teacher. The results of the interview further explained that the learning model carried out by the teacher was by sending videos using the WhatsApp group. The form of learning videos that are commonly sent via WhatsApps group classes contains greetings to students and is continued by explaining the subject matter and assignments that will be done that day. Furthermore, the assignment given can be sent in the form of a video, a Student Worksheet (LKS). The way students do assignments is by doing assignments manually by writing in books then photos of the results of the assignments are sent via WhatsApps chat. To strengthen the assessment, the teacher also adds assignments in the form of a Google Form. Teachers use WhatsApps as a means to collect assignments. The reason for the teacher choosing to use WA is that it is more practical, easier for children to understand, more effective because it does not require a lot of quotas in the learning process. Currently, WA is easier and can be reached by many people. The advantage of using WA is that it is easier to operate and easier in sending questions and materials. Even if you want to have a virtual meeting, the teacher can directly use the WA Video Call feature. WA is simple, effective, and efficient in its use.

The learning model that is the second choice is the supporting application in WhatsApps, with as many as $40 \%$ or 10 teachers. The application model used is Google Class and Google Form. The use of Google Form is used for assignments and conducting evaluations. Another addition is Youtube, namely by uploading videos so that students can watch them. In this study, 15 teachers were using these facilities. The use of Google Form is for student worksheets. The form of assignments given to students varies, not only for academic purposes but also for non-academic assignments.

Another third application option is Google Form with $36 \%$ or 9 teachers. The use of Google Form is for student worksheets. The fourth choice of the application used is Youtube (uploading learning videos) which is used by $20 \%$ or 5 teachers. Short videos related to the material being taught with duration of 10-20 minutes. The video is available on YouTube for a long duration. Through this application, the teacher explores student knowledge, provides direct feedback, and monitors student activities. Another goal is for students to be more enthusiastic about learning because they are motivated by their friends who are present, it can also help reduce boredom in learning by themselves.

The first obstacle experienced by teachers and students at SMAN 2 Tanjung Jabung Timur, is the difficulty of finding an internet network. But in fact, the WA application is also easier because teachers and students use it a lot and can use it. Based on the results of further interviews, with teachers who used online learning models, it was stated that the online model was very suitable for students. At the beginning of online learning, the material was only given through Microsoft Word and then students read so that after a long time students felt bored. When the teacher provides online learning via video, students are very enthusiastic about taking part in learning. Especially when doing practice questions in the form of quizzes through Google Forms, students are very enthusiastic because they can see the correct answers firsthand and they can also see the scores or results of their work directly. Zoom Meetings are only held occasionally because remembering that not all students can access them, especially some students who are constrained by signals.

Online learning in practice has obstacles. The first obstacle, some children don't have (HP). The second obstacle is having a cellphone but being constrained by network facilities or internet connection, hampered in sending tasks due to difficult signals due to frequent blackout. In fact, further data explains that some students do not have their own cellphones, so they have to borrow. Cases like this are very hindering and the teacher has to repeat notifications. The third obstacle is that information is not always accepted directly by students due to the limited internet quota. For example, today there is an assignment, but 5 days later you can open WA. Even at the beginning of online learning students cannot open the WA web file because they do not know the application. The seventh barrier is limited cellphone features, signal constraints, and internet quota. The main obstacle is technically the internet network and the very frequent blackouts. Besides, many students experience boredom and boredom studying online so they sometimes answer questions carelessly. The concentration and motivation of children studying at home and school will certainly be different.

During online learning experiencing several obstacles, the first obstacle is if students feel bored, the teacher must think of a strategy of how to get students out of their boredom zone. Teachers need to be creative in creating online learning that is attractive to students.

The first advantage felt by teachers at SMAN 2 Tanjung Jabung Timur, in online learning, was that it was more practical and relaxed. Practical because it can assign tasks at any time and report tasks at any time. Second, it is more flexible, it can be done 


\section{Use of Application Variations on Online Teaching in the Covid-19 Pandemic Era}

anytime and anywhere. Third, it saves time and can be done at any time. All students can access it easily, meaning it can be done anywhere. Delivery of information is faster and can reach many students through the WA Group. Fourth, it is more practical and makes it easier to take knowledge values, especially when using Google Forms. If you use Google Form, you can immediately find out the grades so that students are more interested in doing assignments. Students are also facilitated in doing it. Students only need to choose the answer that is considered correct by clicking on the answer in question. The fifth advantage is that students can be monitored and accompanied by their respective parents. The sixth advantage is that teachers and students get new experiences related to online learning.

The weakness in online learning experienced by teachers at SMAN 2 Tanjung Jabung Timur, is the lack of student involvement. Student involvement in question can be seen from the results of student involvement in taking full online learning from the beginning of learning to the end of learning. The results showed that only $50 \%$ of students were fully active, $33 \%$ of students were actively involved. Meanwhile, the other 17\%, students who are less active and less participate in online learning.

The hopes of the principal and teachers regarding online learning at SMAN 2 Tanjung Jabung Timur, are the first hope, after conditions return to normal or the Covid-19 outbreak has ended, the teacher hopes that in addition to classroom learning, online learning can still be implemented to train the skills of teachers and students in the era of the 4.0 century. The second hope of this learning is as an alternative for teachers in applying learning models. This aims to increase knowledge and apply the use of technological advances properly. The third hope is that there is special treatment for students who have difficulty learning. The fourth hope is that this online learning model is good to use but needs to be added to the offline learning model. This is because if only online learning alone, the honesty and independence of students in doing assignments is less controlled. So it would be good if this online learning model was continued by adding face-to-face learning. It is hoped that in the future there will be an even better online model to support learning to make it more effective and efficient that can be accepted by students well. The fifth hope is that online learning can be a good solution to support the progress of learning at home in a pandemic like this. The role of parents at home is expected to be as much as possible in accompanying their children to study at home. The positive thing that can be obtained is the children have a personal closeness with their parents.

\section{CONCLUSION}

Referring to the data, discussion, and description above, at the end of this study it can be concluded that education must ensure teaching and learning activities continue, even though students are at home. The solution, educators are required to design learning media as an innovation by utilizing online media. This is by the Minister of Education and Culture of the Republic of Indonesia regarding Circular Number 4 of 2020 concerning Implementation of Education Policies in the Emergency of the Spread of Corona Virus Disease (Covid-19). The learning system is implemented through a personal computer (PC) or laptop connected to an internet network connection. Educators can learn together at the same time using groups on social media such as WhatsApp (WA), telegram, Instagram, zoom applications, or other media as learning media. Thus, educators can ensure students follow the learning at the same time, even though in different places. Educators can also give measurable assignments according to the objectives of the material presented to students. And the media most widely used by teachers are watshap and zoom because these media are almost all students can use, although sometimes they are constrained by the internet network.

\section{REFERENCES}

1) Amira, F., Hamzah, B., Lau, C. H., Nazri, H., Ligot, D. V., Lee, G., Liang Tan, C., Khursani Bin, M., Shaib, M., Hasanah, U., Zaidon, B., Abdullah, A. B., Chung, M. H., Ong, C. H., Chew, P. Y., Salunga, R. E., \& Hamzah, A. B. (2020). CoronaTracker: Worldwide COVID-19 Outbreak Data Analysis and Prediction CoronaTracker Community Research Group Correspondence to Fairuza. [Preprint]. Bull World Health Organ.

2) Anugrah, R. J. (2020). Efektifitas penerapan strategi online marketing oleh umkm dalam masa pembatasan sosial berskala besar (psbb) corona viruses disease 2019 (covid-19). Manova.

3) Burhanuddin, C. I., \& Abdi, M. N. (2020). Ancaman Krisis Ekonomi Global Dari Dampak Penyebaran Virus Corona (COVID-19). AkMen.

4) Darmalaksana, W., Hambali, R. Y. A., Masrur, A., \& Muhlas. (2020). Analisis Pembelajaran Online Masa WFH Pandemic Covid-19 sebagai Tantangan Pemimpin Digital Abad 21. Karya Tulis Ilmiah (KTI) Masa Work From Home (WFH) Covid19 UIN Sunan Gunung Djati Bandung Tahun 2020.

5) Dewayani, T. (2020). Bekerja dari Rumah (Work From Home) Dari Sudut Pandang Unit Kepatuhan Internal. In Kemenkeu.Go.Id.

6) Firman, F., \& Rahayu, S. (2020). Pembelajaran Online di Tengah Pandemi Covid-19. Indonesian Journal of Educational Science (IJES). https://doi.org/10.31605/ijes.v2i2.659

7) Ismail, R., \& Zainal Abidin, S. (2010). Impact of workers' competence on their performance in the Malaysian private service sector. Business and Economic Horizons. https://doi.org/10.15208/beh.2010.14 


\section{Use of Application Variations on Online Teaching in the Covid-19 Pandemic Era}

8) Kemenkes RI. (2020). Pedoman Pencegahan dan Pengendalian Coronavirus Disease (COVID-19). Germas.

9) Nasution, D. A. D., Erlina, E., \& Muda, I. (2020). Dampak Pandemi COVID-19 terhadap Perekonomian Indonesia. Jurnal Benefita. https://doi.org/10.22216/jbe.v5i2.5313

10) Pane, C. D. . (2020). Virus Corona (COVID-19). 18 April.

11) Setiati, S., \& Azwar, M. K. (2020). COVID-19 and Indonesia. Acta Medica Indonesiana.

12) Sety, L. O. M., Syarifuddin, Y., Tina, L., \& Majid, R. (2020). Female Adolescents in attitudes and side effects of consuming iron supplements. Al-Sihah: The Public Health Science Journal. https://doi.org/10.24252/al-sihah.v12i2.15732

13) Siahaan, M. (2020). Increasing the Role of Bank Financial Institutions and Non-Bank Financial Institutions in Providing Optimal Distribution for Communities during the Covid-19 Pandemic. Proceeding Book of The 2 International Conference on Business and Banking Innovations ( ICOBBI ) 2020 " Nurturing Business and Banking Sustainability".

14) Sudjana, N. (2019). Dasar-Dasar Proses Mengajar. In Bandung: Sinar Baru Algensindo.

15) Suryani, Y., Palupi, R., \& Kusuma, A. (2020). Pendekatan modelling keperawatan anak pada orang tua dalam menstimulasi anak usia dini dengan masalah perubahan perilaku dengan kebiasaan menggunakan gadget. Majalah Kesehatan Indonesia. https://doi.org/10.47679/makein.011.62000001

16) Syah, D. Z. R., Utari, D., \& ... (2020). Edukasi Penerapan Protokol Kesehatan Penyelenggaraan Kegiatan Pada Masa Pandemi Covid 19 Di Tpq Masjid Awalulmu'Minin .... Jurnal Pengabdian ....

17) Tri Suci Rokhani, C., \& Negeri Dengkek, Sa. S. (2020). Pengaruh Work From Home (WFH) Terhadap Kinerja Guru SD Negeri Dengkek 01 Pati Selama Masa Pandemi Covid-19. EduPsyCouns: Journal of Education, Psychology and Counseling.

18) Warisyah, Y. (2015). Pentingnya " Pendampingan Dialogis " Orang Tua Dalam Penggunaan Gadget Pada Anak Usia Dini. PROSIDING SEMINAR NASIONAL PENDIDIKAN “Inovasi Pembelajaran Untuk Pendidikan Berkemajuan.

19) Windhiyana, E. (2020). Dampak Covid-19 Terhadap Kegiatan Pembelajaran Online Di Perguruan Tinggi Kristen Di Indonesia. Perspektif Ilmu Pendidikan. https://doi.org/10.21009/pip.341.1

20) Yahaya, A., \& Abd. Majid, N. (2011). Hubungan Antara Budaya Formal Sekolah Dan Gaya Pembelajaran Pelajar Dengan Pencapaian Akademik Pelajar Sekolah Menengah. Educational Psychology and Counseling.

21) Yunus, N. R., \& Rezki, A. (2020). Kebijakan Pemberlakuan Lock Down Sebagai Antisipasi Penyebaran Corona Virus Covid-19. SALAM: Jurnal Sosial Dan Budaya Syar-I. https://doi.org/10.15408/sjsbs.v7i3.15083 